\title{
"Professional development in the field of human resource management of heads and specialists of the innovative organizations"
}

Olga Klopova (D https://orcid.org/0000-0002-2525-6657
Lyudmila Komyshova (Dttps://orcid.org/0000-0001-5033-9238
Marina Simonova (D https://orcid.org/0000-0003-4790-4245

Olga Klopova, Lyudmila Komyshova and Marina Simonova (2018). Professional ARTICLE INFO development in the field of human resource management of heads and specialists of the innovative organizations. Problems and Perspectives in Management, 16(1), 214-223. doi: 10.21511/ppm.16(1).2018.21

DOI http://dx.doi.org/10.21511/ppm.16(1).2018.21

RELEASED ON Wednesday, 07 March 2018

RECEIVED ON

Thursday, 26 October 2017

ACCEPTED ON

Wednesday, 31 January 2018

\section{(cc) EY-No}

LICENSE

This work is licensed under a Creative Commons Attribution-NonCommercial 4.0 International License

JOURNAL

"Problems and Perspectives in Management"

ISSN PRINT

$1727-7051$

ISSN ONLINE

$1810-5467$

PUBLISHER

LLC "Consulting Publishing Company "Business Perspectives"

FOUNDER

LLC "Consulting Publishing Company "Business Perspectives"

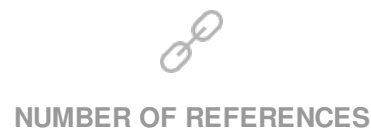

26
NUMBER OF FIGURES

1
ニニュ

NUMBER OF TABLES

1

(C) The author(s) 2022. This publication is an open access article. 


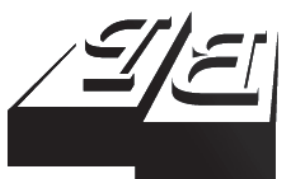

BUSINESS PERSPECTIVES

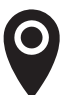

LLC "CPC "Business Perspectives" Hryhorii Skovoroda lane, 10, Sumy, 40022, Ukraine

www.businessperspectives.org

Received on: $26^{\text {th }}$ of October, 2017 Accepted on: $31^{\text {st }}$ of January, 2018

(C) Olga Klopova, Lyudmila

Komyshova, Marina Simonova, 2018

Olga Klopova, Doctor of Economics, Associate Professor of the

Management Department, Russian

Presidential Academy of National

Economy and Public Administration,

Russia.

Lyudmila Komishova, Senior

Lecturer of the Department of

Human Resource Management,

Voronezh State Technical University,

Russia.

Marina Simonov, Doctor of

Economics, Associate Professor of the Department of Labor Economics and Human Resources Management, Samara State University of

Economics, Russia.

\section{(ㄷ)(1) (8)}

This is an Open Access article, distributed under the terms of the Creative Commons Attribution-NonCommercial 4.0 International license, which permits re-use, distribution, and reproduction, provided the materials aren't used for commercial purposes and the original work is properly cited.
PROFESSIONAL

DEVELOPMENT IN THE FIELD

OF HUMAN RESOURCE

MANAGEMENT OF HEADS AND

SPECIALISTS OF THE INNOVATIVE ORGANIZATIONS

\begin{abstract}
The relevance of the studied problem is caused by the necessity of professional development in the field of human resource management of heads and specialists of the innovative organizations in a modern economic situation. In the article, the results of the conducted research of a personnel management system are given in the organizations of the Russian Federation (Voronezh region), and the necessity of creation of professional development system is proved in the field of human resource management of heads and specialists of the innovative organizations. The leading approaches to the research of this issue are the analysis and methodological justification of the psychological and pedagogical conditions which are necessary to realize the system of professional development in the field of human resource management of experts and heads of the innovative organizations. The implemented analysis defined the low level of competence of heads in the field of human resource management of most researched organizations. Professional development in the field of human resource management does not correspond to modern social and economic development conditions. To eliminate this problem the authors suggested theoretical and methodological basic concepts to establish the system of professional development in the field of human resource management of heads and specialists of the innovative organizations.
\end{abstract}

\section{Keywords}

\section{JEL Classification}

professional development, pedagogical conditions, methodological approaches, human resource management, innovative organizations

J44, O15

\section{INTRODUCTION}

Now, in the middle of another economic crisis, which is deepened by cross sanctions of Russia and Western countries, modern organizations are concerned about highly qualified personnel that is interested in self-development and professional growth, since this part of the working population can become one of the tools of innovative economy. Professional development is at the level of chaotic, not connected training events (courses, seminars, trainings, etc.) in which there is no support on specific needs of cultural development of modern heads and specialists in modern social and economic conditions of the development of country, region, organizations, personality. To eliminate this problem, authors suggested theoretical and methodological basic concepts to establish the system of professional development in the field of human resource management of heads and specialists of the innovative organizations. Psychological and pedagogical conditions of this system implementation are also presented in the article. 
In the conditions of continuous development and improvement of market relations in an economic complex of the country, there is a discrepancy of levels of social and economic development of economic formations (Sergeyeva \& Komyshova, 2011). It is caused by many factors providing their level of development depending on the tasks which are being solved at present by national economy and also by initial potential and dynamics of its development. At the same time, human potential plays a crucial role, development of the organizations and economy in general depend on its state. Human resource management is considered to be the major factor that is able to rapidly increase the efficiency of the organizations. The conducted research shows that most Russian organizations could not become strong competitors to the Western companies yet. The human resource (professional knowledge, employees skills) becomes one of the important components in increasing competitiveness of the Russian enterprises and organizations (Simonova et al., 2016). Studies of the relationship between activities in the field of personnel management and the results of business organizations are of particular interest for the goals of this research. A number of foreign studies illustrate a significant positive relationship between the work in the field of personnel management and economic performance of organizations in various economic sectors (Buller, 2012; Guzbus, 2011), which determines the importance of training in the field of personnel management of managers and specialists of innovative organizations.

The effective use of human resources is one of the most powerful foundations of competitive advantage and allows to achieve strategic organizational goals (Boxall, 1992; Rosemond \& Lartey, 2011). And organizations with higher index of human resources management systems (which reflects the level of the human resource management system implementation in the organization) demonstrate higher economically and organizationally significant level of performance (Huselid, 1998).

Now in Russia the unified concept of professional employees development is not elaborated yet. This problem appeared due to the lack of development strategy of additional education. The lag in development of methodological and theoretical bases of professional development in the field of human resource management of heads and specialists of the innovative organizations is explained by the fact that the system of professional development started getting more significance within the concept of continuous education only in recent years.

The analysis of modern pedagogical research taking into account practice of system of domestic education testifies about an increasing interest in the issues relating to professional competence of specialists and heads. However, there is no special research on a problem of system formation of professional development in the field of human resource management of innovative organizations.

Research objective is to create the system of professional development in the field of human resource management of specialists and heads of the innovative organizations. To achieve the goal, it is necessary to solve a number of problems: to carry out the analysis of a personnel management system in the organizations; to determine the level of heads' competence in the field of human resource management of the organizations which focus on the innovative development; to define theoretical and methodological bases of system formation of professional development in the field of human resource management; to designate psychological and pedagogical conditions of this system realization.

\section{METHODOLOGICAL FRAMEWORK}

In the course of the research, the general and private methods of the research were applied. The following methods were used: comparison method; studying of monographic publications and articles; analytical method; methods of observation and generalization; studying of standard and legal base; questioning method. Trial and experimental base is the organizations of the Voronezh region. 
According to monitoring research of the development of the system of continuous vocational education that was conducted in 2013-2015, it is possible to draw a conclusion, the level of development of the organization and its innovative activity is higher, the expansion of continuing vocational education which included employees of all levels, from heads to workers (Klopova \& Komyshova, 2015) is more probable.

Human resource management of successful organizations is a major factor that can repeatedly increase their efficiency. It is connected with the fact that technological modernization of real sector of the Russian economy has to be based on new competences of employees. These provisions are reflected in the last documents of the Government of Russia and the State Duma of Federal Assembly of Russia. At the same time, the main emphasis is supposed to be placed on the increase in labor productivity, decrease in power consumption and material production capacity and other priorities determined by the concept of long-term social and economic development of the Russian Federation and the long-term forecast of technological development of the Russian Federation till 2025.

\section{THE CONTENT OF THE STUDY}

Modern technical and technological approaches to production, transition from labor-intensive to knowledge-intensive processes radically change work characteristics and content of heads (linear managers, project managers) of innovative organizations.

The main objective of the head is to achieve the objectives of the organization by means of other people, their joint group performance (Dessler, 2012; Vashchenko, 2009). Excellent heads are always anxious about enterprise interests; they try to balance the interests of a group and a certain employee, interests of production and social needs of employees. Thus, in activity of modern heads, there are serious changes which form serious "challenges" to higher technical education. An essential part of their work is the issues of personnel organization and management. Profound knowledge in the sphere of professional activity seems to be insufficient to implement highquality projects, to work with people. Readiness to organizational and administrative activity with personnel, which starts at higher educational institution, is becoming more crucial.

Social and professional competence in the field of personnel management is an integrated characteristic of the personality which defines its ability to solve variable problems in the field of human resource management taking into account modern requirements of the state, society and personality and its values (socially important, professionally significant, personally significant), knowledge, skills and experience, reflection as a way of reflecting needs in improvement of level of expertise to professional activity (Barnett, 1994; Zimniaia, 2005; Klopova, 2014).

In this regard, continuous vocational education (APE) faces the task to satisfy educational and professional requirements, professional development of a person, to ensure the compliance of its qualification to changing conditions of professional activity and social environment (Avraamova et al., 2016).

Managerial activity in modern economic conditions differs in tendencies to democratization and creating business partnership that reflects in new approaches to training in the system of professional development in the field of human resource management of headsand specialists of the innovative organizations. The personal developing orientation of educational processes as a leading tendency of modern innovative changes causes the transition from management, authoritative and communicative to humanitarian communicative interaction of entities that implement joint activity (Lobanova, 2002; Spitsyn, 2011). Not to lag behind requirements of time, there is an intensification of educational process on the basis of introduction of interactive educational technologies, creation of psychologically comfortable environment providing freedom for listeners in the choice of educational forms and methods. In the practice of professional development in the field of human resource management, the system of tuition, internship, courses of leading scientists, seminars, trainings, modeling, case technique, method of projects, modular systems are actively used. 
In modern system of professional development in the field of human resource management both in Russia and abroad, distance learning is implemented whose characteristic features are flexibility, modularity, economic efficiency, a new role of a teacher in the course of training, specialized quality control of education, use of specialized technologies and tutorials, effective support on modern transmission media of educational information.

The comparison of the used forms of continuous vocational education at successful (innovative) and unsuccessful enterprises (Table 1) shows that the first ones gravitate towards more contemporary forms of professional development, and the second ones to traditional forms (Alisultanova, 2010).

Table 1. Used forms of additional education at continuous vocational education of successful (innovative) and unsuccessful enterprises in 2015, \%

\begin{tabular}{|c|c|c|}
\hline \multirow{2}{*}{$\begin{array}{c}\text { Forms of professional } \\
\text { training }\end{array}$} & \multicolumn{2}{|c|}{ Enterprises } \\
\hline & Successful & Unsuccessful \\
\hline Programs less than 72 hours & 71.4 & 77.6 \\
\hline Programs that last 72 hours & 71.4 & 53.4 \\
\hline $\begin{array}{l}\text { Continuous vocational } \\
\text { education that lasts up to } 500 \\
\text { hours }\end{array}$ & 50.0 & 17.2 \\
\hline $\begin{array}{l}\text { Continuous vocational } \\
\text { education over } 500 \text { hours }\end{array}$ & 31.0 & 6.9 \\
\hline Trainings. seminars & 88.1 & 89.7 \\
\hline Tuition & 78.6 & 91.4 \\
\hline Programs MBA & 23.8 & 15.5 \\
\hline
\end{tabular}

From the data presented in the table it is visible that continuous vocational education in the area of development and in the area of stagnation doesn't have only different scale, but also different forms.

In 2014-2015, the authors of the article conducted a research to define the conditions of a personnel management system in various organizations of the Voronezh region. Thirty enterprises participated in the research, among them there were large, medium-sized and small organizations. We specify the most typical features of human resource management in the studied organizations.

The attitude of owners and heads of the organizations towards the significance of human resources development for business.
In the majority of the studied organizations, there are special work structures with personnel. On a question: "Is there a special structure in your organization on human resource management (human resources department, service of human resource management)?" $87 \%$ of respondents answered positively, 13\% answered negatively.

In small and medium-sized organizations, as a rule, top officials deal with personnel issues. It is positive. However, this resource isn't used effectively providing big loading and insufficient preparation in the field of human resource management.

At the interviews with heads, there was revealed that $65 \%$ think that "work with personnel is a number of specific actions directed to continuous employees management". The person is considered as one of the elements of formal structure that brightly demonstrates that heads don't have sufficient knowledge in the field of modern concepts of human resources management. It is typical that only $24 \%$ of heads regularly get acquainted with information materials on human resource management. So heads have low level of competence in the field of human resource management.

In the majority of the studied organizations, heads have no knowledge, experience, don't know how to use modern technologies of personnel management. In the analysis of heads professional development in the field of human resource management in the studied organizations, the following data are obtained.

From 30 studied organizations heads had professional development in the field of human resource management in 9 organizations, in 21 organizations there is no direction of professional development.

The question was asked: "How do you improve your knowledge in the field of human resource management?" (Figure 1)

From provided data it is possible to draw a conclusion that lack of basic competences in human resource management (received when studying 


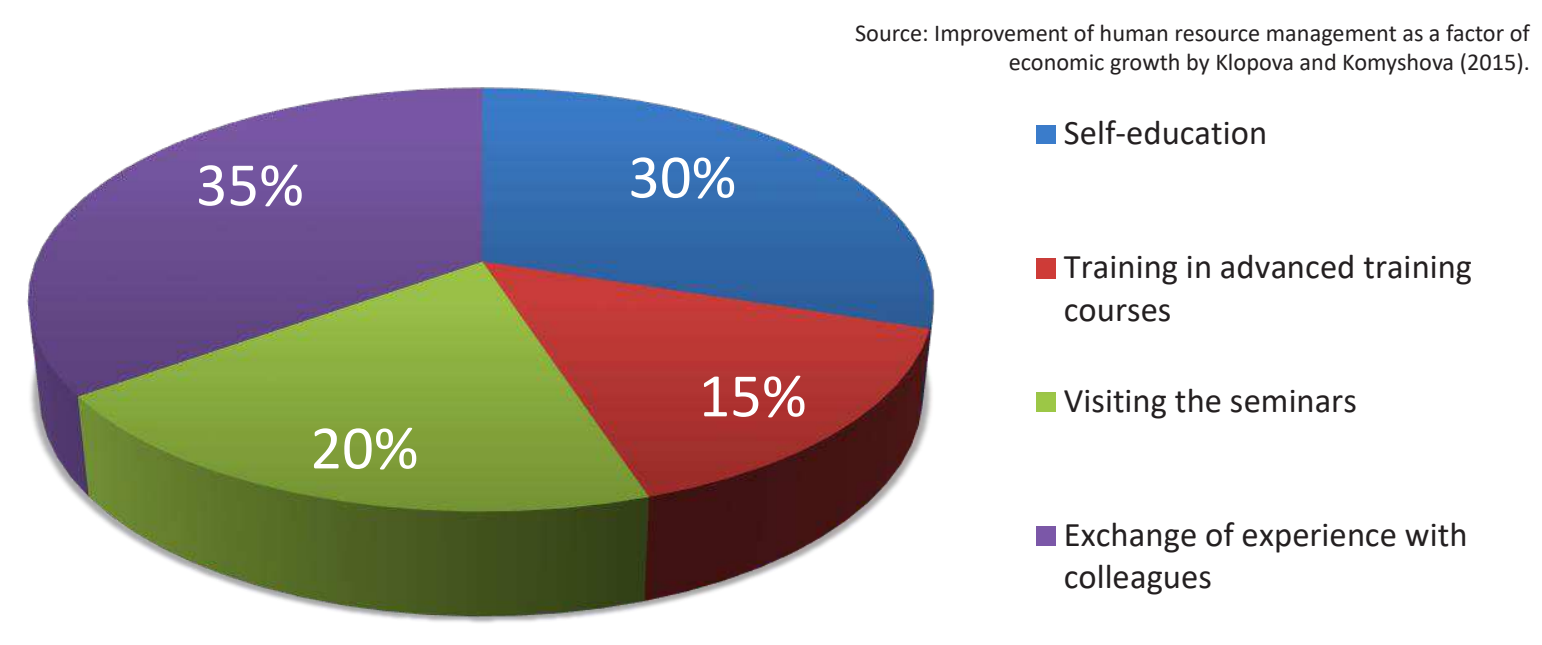

Figure 1. Knowledge sources of human resource management used by heads

at higher education institution) is compensated by various sources. Of course, also participation in seminars, and participation in "round table discussions", in professional clubs which give the chance to fill up the knowledge base and to fulfill skills, to exchange experience with colleagues or just to ask help from them.

However, it would be desirable to notice that oneand two-day seminars, and also participation in meetings of professional clubs, can't solve the problem of their system preparation. And, as it seems to us, in today market situation the issue of heads training in the field of human resource management should be considered as a necessity to create the system of professional development that reflects their needs.

The implemented analysis of creating the system of professional development in the field of human resource management in large Russian corporations showed that professional development in this area became a necessary condition of personnel development in large companies (Vinogradov, 2011). At the same time, proceeding from own interests, each corporation applies its forms and methods how to form the system of professional development of specialists and heads who are defined within primary groups: creation of training centers and corporate universities (JSC Russneft), together with higher educational institutions; own corporate universities (JSC Sberbank, JSC "Russian Railways", JSC Severstal). The practice of creating own business schools on the basis of innovative enterprises and organizations is widespread. For example, business school Spetsialist-M, structural division of the JV Sodruzhestvo resident company, focuses on production which requires more and more from heads and experts qualification and realizes several training directions. The business school Spetsialist-M gives updated knowledge and skills to listeners in the field of human resource management by means of own innovative technologies. Now within continuous vocational education in the field of innovative technologies management employees of candidate pool, heads of structural divisions of military-industrial corporation "NPO mashinostroeniia" and specialists of JSC Rosagroleasing had professional development.

In our opinion, experience of professional development in the field of human resource management of specialists and heads seems to be interesting for us in a training center "Human resource management" on the basis of specialized department of the State Management University. The programs of continuous vocational education which is realized within training center focus on a wide range of listeners: heads and specialists of services of human resource management, heads of high and average levels of management, heads of divisions and branches, employees in a candidate pool who claim on senior positions. The purpose of the programs of continuous vocational education is to systematize knowledge of listeners in the field of human resource management, to create a complete idea of methodology, system, strategy, technology of human resources management. 
The basis for these programs is the concept of training of specialists on human resource management. Its feature is maintenance of balance between economic, managerial and behavioral disciplines in the plans of study.

Visualized lectures, practical sessions with elements of training preparation, group work methods and educational videos, business simulations, case study (the analysis and solution of specific business situations), written analytical works on the basis of real management practice, professional consultations on current professional problems are used in the course of training (Mathis \& Jackson, 2011).

The experience of the Voronezh Institute of High Technologies is the example of competence development of experts and heads of innovative organizations in the field of human resource management at the regional level. In the program of proficiency enhancement "Human resource management", listeners are provided with the analysis of modern problems of workforce management. The course gives information on technologies of formation of a human resource system and ways of its transformation depending on change of a company strategy; it also shows the methods of effective team building, bases of fundamental principles of employment legislation and record keeping in personnel work, and modern information technologies of human resource management. The duration of the course is 510 hours.

According to the state plan of preparation of professional managers for the organizations of the national economy, the program of professional retraining in the field of human resource management is implemented by the center of preparation of professional managers in the Voronezh State University. Specialists and heads of enterprises and organizations of all forms of ownership are invited to participate in this program. Training of specialists is carried out according to the basic educational programs, which provide professional retraining (550 hours, including 180 hours of language training) in the field of management, marketing, finance, human resource management. Upon training completion, the internships at foreign and Russian enterprises are organized within the program. Such internships can last from 2 weeks up to 2 months. There are requirements of competitive selection for participants: age up to 40 years; higher education; general length of employment not less than 5 years; experience at managerial positions not less than 2 years.

While organizing programs of extended education, MBA (master of business administration) finds wide application. At the present time, proficiency enhancement in the field of human resource management by means of receiving MBA education is for those who already have a certain degree of training and experience in senior positions (Mondy \& Martocchio, 2016). Being strategically and practically targeted, training helps to systematize current knowledge, to integrate them and "to build on" new one. It is intended to acquisition of working knowledge and skills, aimed at quick and effective decision-making and solution of practical problems in the field of human resource management. As a result, MBA program graduates are able to fulfill work of top and midlevel executives.

Nowadays, team-building events are especially popular among heads and specialists of organizations (Science, technology and innovation in Europe, 2010). In modern educational practice, training focuses on drilling of the studied material. This means that in the course of simulation of specially set situations, students have an opportunity to develop and solidify necessary knowledge and skills, to change attitude towards their own experience and approaches applied in work. Training programs are implemented by many educational organizations, and also by training and consulting companies (Moscow Business School, Russian School of Management, the training center "Sinton", the consulting company "BuroAkzent", Center of Scientific and Technical Information "Progress", etc.)

In the team-building events, dedicated to the issues of human resource management, various methods and technologies of active learning like business, role-playing and simulation games, case study and group discussions are used.

In case of competence development in the field of human resource management, trainings of leadership skills of executive heads are becoming widespread. Over its course, people master various as- 
pects of management (motivation of subordinates, decision-making, organization of work in teams, etc.) (Goyer et al., 2014). As a result of such training, heads and specialists of organizations do not only analyze the process of management activity (planning, decision-making, assessment, control, etc.), but also acquire knowledge and algorithms of solution of managerial tasks in the sphere of personnel management and work on development of their leadership potential.

At the same time, the considerable part of programs, focusing on external integration, can't be isolated within corporate training. It should be connected with existing educational standards, a set of competences, which are going beyond one branch, accounting of interindustry and general economic tendencies, including features of activity of innovative enterprises (Tikhomirov, 2001). It requires formation of the corporate training programs in direct correlation with the state concept of extended education in the field of human resource management.

Experience of training of specialists and executive heads for the sphere of innovative business by a number of the Russian educational institutions, and also foreign experience of training of managers, responsible for transfer of innovative technologies in the business environment, demonstrate that educational programs should be oriented to formation of a wide range of the competences, necessary for transformation of intellectual products into effectively operating business. They are also focused on preparation and retraining of the professionals who already have the higher education and experience in science, production or business.

\section{RESULTS}

It is obvious that efficiency of competence development and the whole system of supplementary vocational education depends on concerted effort of all its elements, on a complex approach to their improvement on the basis of development of scientific-research, academic and teaching activity and their interrelation. Justification of an opportunity for development of the system of competence development in the field of human resource management of executive heads and specialists of the innovative organizations is the fact that it provides creation of non-standard, individual content of training, taking into account life experience, the level of the previous preparation, social and psychological features of students (Dorozhkin, 2005).

Management activity of an executive head is many-sided, multipurpose, multi-attribute, its complexity is that it consists of components of different professions. Executive heads and specialists of innovative organizations act as facilitators (leaders), innovators, administrators (Sergeeva \& Komyshova, 2015). At the same time, considering differences in designed purpose of each kind of activity, common for them is that the activity in the field of human resource management usually consists of separate stages of the management process:

- provision of an activity plan of personnel, including setting goals for the coming period of work and programming of actions, necessary for their performance;

- organization of personnel activity both on the scale of the whole enterprise, and within its functional subdivisions;

- planning of manpower resources, its recruitment, familiarization with production and training;

- personal management, motivation and stimulation of labor activity, provision of information and cooperation;

- managerial decision-making;

- control over accomplishment of objectives by performers and over operational efficiency;

- improvement of activity of corporate stuff in general.

All these questions should be reflected in the content of training programs of experts and executive heads of innovative organizations.

Modern theories of management determine the influence on formation of the proficiency en- 
hancement system of executive heads and specialists of innovative organizations (Knowles, Holton, \& Swanson, 2005). According to these theories, based on the comprehensive approach, we suggest using three groups of conditions, identifying the results of competence development:

- efficiency of performance;

- integration;

- flexibility.

These operating conditions of the system can be the basis for the structure of carrying out the analysis of the effect, expected competence development in the field of human resource management of experts and executive heads of innovative organizations.

We assume that the effect will be shown only in case, if in consequence of implementation of measures for proficiency enhancement of executive heads and specialists, the socio-professional competence is created in the field of human resource management (Sergeeva \& Komyshova, 2011). This competence promotes their adaptability for various situations. This is the criterion for evaluation of competence development in the field of human resource management of specialists and executive heads of innovative organizations. We have defined the highlighted conditions:

- Performance efficiency. Direct task performance occupies a central position in the discussion concerning personnel training and competence development. At the same time, at first impact on professional qualification is considered, then on motivation and, at last, on personnel employment. The qualification indicator reflects influence on ability to work effectively, motivational indicator shows influence on aspiration to perform work, and impact on personnel employment means an opportunity to hire qualified employees, who are ready to perform a necessary task. First of all, motivational influence is achieved due to proficiency enhancement, if it opens or, at least, makes it easier to find opportunities for future career. Besides, the motivational effect is reached, when competence development stimulates high-quality and reliable work performance.

- Integration and management. Competence development, providing information on the purposes and the major intra organizational interrelations, should encourage integration and purposeful action of employees.

- Flexibility. Proficiency enhancement facilitates innovative effect and increase mobility. Both of these factors are united by the concept "effect of flexibility". Due to competence development in the field of human resource management, the organization, executive heads and specialists acquire new knowledge, skills, and acquirement, which promote essentially new solutions of personnel problems. Competence development in this area should promote creation of innovative climate at the enterprise. This is practical relevance of the conducted research.

\section{DISCUSSION}

In modern scientific and pedagogical research, determination of the importance of the proficiency enhancement process, which has a number of organizational and substantial features in comparison with the system of basic education, is often observed more and more. Competence development is the learning activity, focused on employee readiness to perform more difficult labor functions. It provides acquiring new general-theoretical and technology-specific knowledge, expansion of the variety of skills and acquirement, better understanding of connection between science and technology. This is one of the forms of assimilation of progressive experience, which purpose is to improve labor productivity.

Various authors don't always agree about the interpretation of the essence of proficiency enhancement in their publications.

The analysis of publications of Russian and foreign scientists defines the specifics of proficiency enhancement of adults as training of people, who are able to apply their knowledge in the changing conditions and whose main 
competence consists in their ability to organize continuous self study throughout their life. The analysis of modern pedagogical research of scholars, taking into account practicum of domestic education system, indicates the increasing interest in the issues, relating to professional competence of specialists and executive heads. At the same time, the problem of formation of the competence development system in the field of human resource management of specialists and executive heads of innovative organizations requires further research and development.

\section{CONCLUSION}

According to the results of our research, it is possible to conclude that it is necessary to consider the following psycho-pedagogical conditions to realize proficiency enhancement system in the field of human resource management of experts and executive heads of organizations, focused on innovative development:

- creation of non-standard, individual content of training, taking into account life experience, the level of the previous preparation, social and psychological features of students;

- intensification of the educational process on the basis of introduction of innovative technologies of training, creation of psychologically comfortable environment, which provides freedom of listeners while choosing educational forms and methods;

- diagnostics of educational needs, the skill level and individual difficulties in the field of human resource management of specialists and executive heads;

- change of the role of a teacher due to strengthening of pedagogical support function, necessity of developing special skills and methods of training courses;

- the emerging role of students in defining the content of proficiency enhancement programs and organization of their training process.

\section{REFERENCES}

1. Alisultanova, E. D. (2010). Competency-based approach in the engineering education. Publishing house: Akademiia Estestvoznaniia.

2. Armstrong, M., \& Taylor, F. (2014). Armstrong's Handbook of Human Resource Management Practice. London: Kogan Page.

3. Avraamova, Ye. M., Karavay, A. V., Klyachko, T. L., \& Loginov, D. M. (2016). Мониторинг дополнительного профессионального образования в России [Monitoring dopolnitelnogo professionalnogo obrazovaniya $v$ Rossii] (96 p.). Moskva: Izdatelskiy dom "Delo" RANKHiGS. Retrieved from http:// www.ranepa.ru/images/docs/nayka/delo/Avraamova_blok.pdf
4. Barnett, R. (1994). The Limits of Competence. Knowledge, Higher Education and Society. Buckingham, UK: Open University Press.

5. Boxall, P. F. (1992). Strategic HRM: a beginning, a new theoretical direction. Human Resource Management Journal, 2(3), 60-79. Retrieved from http://onlinelibrary.wiley.com/ doi/10.1111/j.1748-8583.1992. tb00260.x/abstract

6. Buller, P. F. (2012). Strategy, Human Resource Management and Performance: Sharpening Line of Sight. Human Resources Management Review, 22(1), 43-56.

7. Dessler, G. (2012). Human Resource Management. New York: Prentice Hall.
8. Dorozhkin, E. M. (2005). Supplementary vocational education of forestry professionals: methodology, theory, practice. Moskva: VentanaGraf.

9. European Union (2010). Science, technology and innovation in Europe.

10. Goyer, M., Reinecke, J., \& Donaghey, J. (2014). Globalization and labour market governance. In Adrian Wilkinson, Geoffrey Wood \& Richard Deeg (Eds.), The Oxford handbook of employment relations: comparative employment systems. Oxford handbooks in business and management (pp. 631-636). Oxford: Oxford University Press.

11. Guzbus, S. (2011). Impact of 
the Strategic Human Resource Management on Organizational Performance: Evidence from Turkey. International Journal of Human Resource Management, 22(8), 1803-1822.

12. Huselid, M. A. (1995). The Impact of Human Resources Management Practices on Turnover, Productivity, and Corporate Financial Performance. Academy of Management Journal, 38(3), 635-872.

13. Klopova, O. K. (2014). Формирование системы непрерывного образования в области управления персоналом [Formirovaniye sistemy nepreryvnogo obrazovaniya $v$ oblasti upravleniya personalom]. Voronezh: "Nauchnaya kniga". Retrieved from https://search.rsl. $\mathrm{ru} / \mathrm{ru} / \mathrm{record} / 01007542338$

14. Klopova, O. K., \& Komyshova, L. N. (2015). Совершенствование управления человеческими ресурсами как фактор экономического роста [Sovershenstvovaniye upravleniya chelovecheskimi resursami kak faktor ekonomicheskogo rosta]. Region: sistemy, ekonomika, upravleniye, 3(30), 91-98. Retrieved from https://elibrary.ru/item. asp?id $=24314758$

15. Knowles, M. S., Holton, E. E., \& Swanson, R. A. (2005). The Adult Learner: The Definitive Classic in Adult Education and Human Resource Development (6th ed.). London, New York. ELSEVIER Butterworth Heinemann.

16. Lobanova, T. N. (2002). Построение модели ключевых компетенций [Postroyeniye modeli klyuchevykh kompetentsiy]. Spravochnik po upravleniyu personalom, 11, 38-42.

17. Mathis, R. L., \& Jackson, J. H. (2011). Human Resource Management. South-Western Cengage Learning.

18. Mondy, R., \& Martocchio, J. J. (2016). Human resource management (14th ed.). Human Resource Management, Global Edition.

19. Rosemond, B. (2011). The Effect of Human Resource Management Practices on Corporate Performance: A Study of Graphic Communications Group Limited. International Business Research, 4(1), 271.

20. Sergeyeva, S. I., \& Komyshova, L. N. (2011). Задачи и функции образовательных систем в условиях реформирования системы образования [Zadachi i funktsii obrazovatelnykh sistem v usloviyakh reformirovaniya sistemy obrazovaniya]. Современное образование: содержание, технологии, качество: материалы XVII международной научнометодической конференции [Sovremennoye obrazovaniye: soderzhaniye, tekhnologii, kachestvo: materialy XVII mezhdunarodnoy nauchno-metodicheskoy konferentsii] (pp. 162-163). Retrieved from https://elibrary.ru/item. asp?id $=26248508$

21. Simonova, M. V., Ilyukhina, L. A., Bogatyreva, I. V., Vagin, S. G., \& Nikolaeva, K. S. (2016). Conceptual Approaches to Forecast Recruitment Needs at the Regional Level. International Review of Management and Marketing, 6(S5), 265-273. Retrieved from https:// papers.ssrn.com/sol3/papers. cfm?abstract_id=2841575
22. Spitsyn, V. V. (2011).

Особенности

инновационного развития

высокотехнологичных

и среднетехнологичных отраслей в России [Osobennosti innovatsionnogo razvitiya vysokotekhnologichnykh i srednetekhnologichnykh otrasley v Rossii]. Vestnik Tomskogo gosudarstvennogo universiteta, 342, 166-172.

23. Tikhomirov, Yu. A. (2001). Teoriya kompetentsiy. Moskva: Yurinformtsentr.

24. Vashchenko, D. G. (2009). Изучение уровня сформированности профессиональных компетенций молодого специалиста [Izucheniye urovnya sformirovannosti professionalnykh kompetentsiy molodogo spetsialista]. Vestnik Tomskogo Gosudarstvennogo Pedagogicheskogo Universiteta, 9(87), 5-10.

25. Vinogradov, B. (2011). Подготовка кадров для высокотехнологичных предприятий [Podgotovka kadrov dlya vysokotekhnologichnykh predpriyatiy]. Promyshlennyye vedomosti, 3-4. Retrieved from http://www.promved.ru

26. Zimnyaya, I. A. (2005).

Социально-профессиональная компетентность как целостный результат профессионального образования [Sotsialno-professionalnaya kompetentnost kak tselostnyy rezultat professionalnogo obrazovaniya]. Trudy metodologicheskogo seminara "Rossiya $v$ Bolonskom protsesse: problemy, zadachi, perspektivy", 7-11. 